\title{
The Effect of Biodiesel Market on Economic Growth: Policies in the European Union \& Turkey
}

\author{
Fatih Çemrek ${ }^{a}$, Hüseyin Naci Bayraç, \\ a Eskısehır Osmangazi University, Turkey fcemrek@ogu.edu.tr, https://orcid.org/0000-0002-6528-7159 \\ b Eskişehir Osmangazi University,Turkey nbayrac@ogu.edu.tr, https://orcid.org/ 0000-0001-9212-987X
}

\section{ARTICLE INFO \\ Research Article \\ 2020, Vol. 3(1), 10-27 \\ e-ISSN 2667-5927 \\ Article History: \\ Received: 16.09 .2020 \\ Revised: 25.11.2020 \\ Accepted: 12.12 .2020 \\ Available Online: 25.01.2021}

JEL Code: Q4, Q48, Q42

Keywords: energy, energy policy, alternative energy sources, biodiesel, panel data analysis
The Effect of Biodiesel Market on Economic Growth: Policies in the European Union \& Turkey

\section{Abstract}

Energy is one of the main inputs of economic growth. The energy supply will become secure, in the fight against agricultural development and global warming, biodiesel, which increases the production of vegetable oil and the recovery of waste vegetable oils, has started to take a large place in energy and agriculture policies. The European Union and Turkey implemented various incentives and support policies for biodiesel and oil seeds planted that are made compulsory mixed prepared. The aim of this study is the structure of the EU and biodiesel fuel production with markets in Turkey and analyzed using panel data to examine the relationship between economic growth and assessing the impact of policies. This study biodiesel for 29 countries from 2008 to 2016 between the years including Turkey found (thousand tonnes) Production and Gross Domestic Product (GDP Million Euro) were examined through the relationship between the annual series of panel data analysis. According to CD test results, cross-sectional dependence exists for biodiesel production. IPS (Im, Peseran and Shin) and ADF-Fisher unit root test was applied for economic growth and biodiesel production series As a result of the econometric analysis, it is seen that the fixed effects model is valid for GDPBiodiesel models. Accordingly, the biodiesel series has a positive effect on the GDP and the increase in biodiesel production affects the GDP in the direction of increase.

To cite this document: Çemrek, F.\& Bayraç, H. N. (2021) The Effect of Biodiesel Market on Economic Growth: Policies in the European Union \& Turkey, BILTURK, The Journal of Economics and Related Studies, 3(1), 10-27. doi: 10.47103/bilturk.796162 


\section{Introduction}

Fossil fuels such as oil, natural gas and coal constitute $80 \%$ of total energy resources consumed in the world economy. Along with these resources being on the edge of depletion, environmental problems caused by the overuse of the resources has accelerated the efforts to find alternative energy resources for the countries and aroused the interest in renewable energy resources. Biomass energy, which composes most parts of renewable energy resources, consists of non-fossil biologic-based organic materials.

Biomass energy is defined as plant-based energy resources which can be in solid, liquid or gas forms having commercial value and certain standards, and these resources are produced through various physical, chemical and biological reactions of agricultural and animal based products existing in nature.

Biodiesel, in biofuels group constituting biomass energy resources in liquid form, is now named as the fuel of the third millennium. Agricultural products are the raw materials for biodiesel, and this places emphasis on achieving rural development from the point of agricultural sector and producers. Moreover, as being quickly and easily degradable in nature, biodiesel does not cause any toxic effects and contributes to the reduction of green house effect since $\mathrm{CO} 2$ is used for photosynthesis while getting biodiesel out of agricultural products.

At first, high costs of biofuels, which emerged as a new industrial sector, made the competition with the classic liquid fuels such as petrol and diesel difficult. For this reason, government should support the raw material production with low costs for biofuels besides the necessary fuel processing plants for consumption, and structure logistics like distribution-transportation and storage. The countries' being aware of this fact have put some support policies into practice to increase biofuel production and consumption.

In this study, after discussing the biodiesel market structure and implemented policies in the EU and Turkey, the relationship between fuel production and economic growth is examined with panel data analysis and the implemented policies are evaluated.

\section{Biodiesel and Its Properties}

Biodiesel is a reneweable and energy-efficient fuel that is non-toxic, biodegradable in water and has lesser exhaust emission. It can also reduce greenhouse gas effect and does not contribute to global warming due to lesser emission. Because it does not contain carcinogens and its sulphur content is also lower than the mineral diesel. Biodiesel can be used, storage safely and easily as a fuel besides its environmental benefits (https://www.intechopen.com/books/biofuel-s- 
engineering-process-technology/novel-methods-in-biodiesel-production, date of access: 04.08.2018).

Biodiesel is an eco-friendly and renewable liquid biofuel which is produced from fresh or waste oils, or animal fats through various chemical processes (Aransiola etc., 2014; 276). In practice, it is also called as biodiesel, green energy, green diesel, super diesel, diesel-bi, or as in colloquial speech, oil diesel. The prefix bio- means related to or using living things, and the root "diesel" means it is a diesel fuel.

Biodiesel is a renewable liquid biofuel produced from oily seeds such as canola (rapeseed), sunflower, cotton, palm oil, cottonseed, corn, soy, safflower, and jatropha, and wastes of these oils (waste oils from homes, industrial places, cafeterias, and etc.) as well as animal fats (such as slaughterhouse, fish, chicken fats) through chemical methods (Dağdelen, 2015; 7). Biodiesel is mostly produced from soy in the USA, and in Europe from canola. In tropical regions, palm, coconut and jatropha oils are made use of for biodiesel production. Apart from these, sunflower, corn, safflower, cotton and peanut are among alternative biodiesel raw materials. In the last years, seaweed has also been used to make biodiesel. However, as it costs high to produce biodiesel from seaweed, nowadays it is not widely used. In today's conditions, mostly vegetable oils are favored as raw materials for biodiesel.

Biodiesel is used in diesel cars as motor fuel, in heating systems like heating boiler, stove, etc., while wiping off paints as solvent, cleaning up engine parts as engine oils, producing brick and terra cotta, cleaning petrol spilled on water or land, coating building forms and as hydraulic liquid. The properties of biodiesel vary according to oil source and alcohol type used in the production, and the top-quality biodiesel is obtained from vegetable oils.

In the world economy, biodiesel is considered to be a new area of investment which is eco-friendly, hinges on domestic raw material, has an important place in integrating agriculture with industry, and has the potential to enable new job opportunities and employment areas. As biodiesel production requires a low production technology, it has been spreading rapidly in the country. Biodiesel's having higher oxygen makes combustion easier, and so this decreases carbon monoxide and hydrocarbon amounts which are released as a result of burning and which cause global warming. Also, it minimizes the damage to the environment, like bioethanol, due to including low sulphur.

Biodiesel can be used as pure fuel or after blending it with diesel fuels produced from petroleum. Biodiesel which gives $88-95 \%$ of the energy amount provided by diesel increases the oil ratio and amount of fuel when mixed with diesel, and this improves the engine's performance. In practice, biodiesel is usually mixed with diesel from petroleum, and is called as B2: $2 \%$ Biodiesel + $98 \%$ Diesel, B5: $5 \%$ Biodiesel + $95 \%$ Diesel, B20: $20 \%$ Biodiesel + $80 \%$ Diesel, B100: $100 \%$ Biodiesel 
(Pure Biodiesel). Moreover, in some scientific research, it is also described as B50 (50\% biodiesel $+50 \%$ diesel) (Karaosmanoğlu, 2002, 52).

Pure biodiesel and diesel-biodiesel mixtures can be used in any diesel engines without any necessary changes or after some minor modifications. For biodiesel, EN 14214 and EN 14213 EU Standards and ASTM D 6751 American Standard are valid. In Turkey, TS EN 14214 based on EN 14214 is in effect for Autobiodiesel Standard in transportation, and TS EN 14213 Fuel Biodiesel Standard is for using biodiesel for heating (Yaşar, 2009; 66).

One of the biggest obstacles to large scale biofuel production is high costs when compared to conventional fuels. To IEA, with today's technology biodiesel production cost twice, three times more than petrol and diesel. For this reason, it is stated that the problem caused by differences in costs can be eliminated by governmental incentives. In order to develop their own industries and to make biofuels compete with conventional fuels, developing countries should specify which incentives and subventions they will provide and deal with the problems in the process. Socio-economically, biofuel is a line of business which can present a number of job opportunities and income to thousands of people as a result of oily seed cultivation with the sustainable development in the country. Growing oily seeds and programs targeting biofuel production specifically facilitates the use of idle lands.

Comparing biodiesel fuels with diesel fuels, generally both fuels are spotted to have similar properties in common in structure. However, due to some properties such as boiling and flash point and high cetane number, biodiesel is accepted to be more advantageous. Especially, elevation of boiling and flash point is important for safety conditions such as transportation and storage, and also high cetane number contributes engine's performance with the energy provided.

\section{Biofuels and biodiesel market and policies in EU and Turkey}

EU energy policies mainly hinge on the thought of providing cheaper, better quality and sustainable service to the consumers. While performing this, it is aimed to allow energy market to be competitive, ensure the security of supply and save the environment on the basis of sustainable development (Yorkan, 2009; 31).

Despite being one of the areas with the most energy consumption in the world, the EU is dependent on outside energy resources due to lack of domestic energy resources. The EU's energy dependency in 2010 was 52, $6 \%$, and this percentage steadily increased as 53,4 \% in 2014 and $54 \%$ in 2015 . The percentage is estimated to be $57,4 \%-59,1 \%$ until 2030 (http://ec.europa.eu/eurostat/tgm/table.do?tab=table\&init=1\&language=en\&pco de=tsdcc310\&plugin=1). To reduce energy dependency and switch to low carbon 
economy, the EU has decided to save coals' share in total energy consumption, to increase natural gas' share, to create maximum safety conditions for nuclear power plants and to increase renewable energy resources' share as principal implementation tools (Aytüre, 2013; 37).

According to "20-20-20 Goals", which were designated regarding renewable energy resources directive dated June 2009 (2009/28/EC) and in a way bind all the members of the EU, in 2020 all across the union, it is stipulated that $20 \%$ of the energy consumption must be provided from renewable sources (the EU council revised this goal as $27 \%$ for 2030 in October, 2014), energy productivity must be increased $20 \%$, and finally energy consumption must be decreased $20 \%$. In the same document, it is also aimed to derive $10 \%$ of the energy used in transportation in the EU from renewable energy resources (Bayraç vd., 2018; 83) and this was proposed to be obtained highly from biofuels. To reach the goals set, most of the union members have put numerous encouraging and incentive implementations into practice since 2003. A wide variety of direct or indirect policies such as tax exemption, tax immunity, quotas, compulsory mixture ratios have been carried out to influence biofuel production (Wetterlund vd., 2012; 462).

While establishing biofuel policies, indicators such as GDP's of countries, cultivated lands, yields from lands, the share of agricultural employment in labor force, transportation demand per capita, fuel import dependency, number of cars per capita and carbon emission are taken into consideration (Çelebi ve Uğur, 2015; 28). In the last periods, the biggest factor in the dramatic rise of biofuels production and consumption has been the country's encouraging production and consumption through supports in this sector. By setting biofuel production and consumption goals, the countries want to reach these goals with various support tools.

Biofuels are liquid fuels made from biomass. The major raw material of these fuels which are regarded as first generation biofuels including biodiesel and bioethanol is agricultural product. Bioethanol is produced by fermenting and distilling sugar beet and sugar cane and also by first saccharizing plants including corn, wheat, barley, rye, and potato and then fermenting and distilling them. However, biodiesel is made from oily plants, for instance canola, soy, safflower, cotton, palm, sunflower. C4 energy plants to be used as biofuel raw material are especially grown on lands unsuitable for agricultural production. In modern agriculture plans, it is aimed to allocate $30 \%$ of agricultural lands for feed and $20 \%$ for energy plants (Horuz vd, 2015; 69).

Second generation biofuels are produced by means of high technology generally from woody and carboniferous lignocellulozic materials which are agricultural products grown as food but noncompetitive in production and consumption. During the production of these fuels, 
Cellulose-intensive organic materials and fibers, including seaweeds, meadow, grass, weed, poplar, willow, eucalyptus, switchgrass, miscanthus are utilized along with industrial waste and city solid waste (Özertan, 2008; 21).

Biofuel production enables both assisting rural development and creating employment by giving preference to domestic agricultural products of the country as raw materials for the production. Countries usually give weight to one kind of biofuel production. Generally, focusing only on bioethanol or biodiesel production is preferred to ensure economic efficiency. Thus, countries specialize in one kind of agricultural product appropriate to climate conditions and they make use of this product in biofuel production.

Both the USA and Brazil prefer bioethanol as biofuel, but while corn is favored in the USA, in Brazil sugar cane is mostly opted for bioethanol production. In countries such as Indonesia and Malaysia, biodiesel are mostly produced from palm oil.

Biofuel consumption policies differ among countries. Some implement various incentive policies aiming at biofuel consumption, whereas the others make biofuel consumption mandatory by means of law enforcements and struggle to increase biofuel consumption with the determined numerical goals.

\subsection{In the European Union Biodiesel Market and Policies}

In the EU, biodiesel production was small-scaled and nonstandard in the 1980s, but today the EU has become the world leader in biodiesel production. Main reasons why biodiesel production has developed so quickly in the union are development in diesel technology, increase in demand for diesel vehicles, increase in the number of diesel cars in transportation and having more environmental problems resulting from energy.

Every year, transportation sector emits $14 \%$ of the greenhouse gases released to the atmosphere. $3 / 4$ of the greenhouse gas emission in this sector is because of road transportation (Bayraç vd., 2018; 41). Particularly, as the increase in greenhouse gases substantially results from transportation sector, and due to having more environmental problems and external dependency's being around $54 \%$, the union has shown special interest in biodiesel.

After the EU's signing Kyoto Protocol, in order to decrease emission resulting from greenhouse gases, biodiesel, which is relatively more eco-friendly than diesel, has been given prominence. Supports given to agricultural products as a consequence of Common Agriculture Policy (CAP) reforms has also influenced the production of energy plants positively (Yaşar, 2009; 69). Thus, it has become compulsory to allocate $15 \%$ of the cultivation sites for pulses and oily seed plants, and moreover 
tax exemptions and other incentives for biofuels have been applied around the union.

As a result of CAP, notably oil production for food has been increased by supporting oily seed plants and biodiesel sector has started to improve in parallel with sufficient and regular raw material supply for biodiesel production. To the EU's 2020 goal of $10 \%$ biofuel in transportation, $1 \%$ in 2004 reached 5,4 \% in 2013 and $5,9 \%$ in 2014 (Eurostat, 2016). The EU has decided on $20 \%$ in 2020, and $30 \%$ in 2030 for biofuel consumption.

In the success of the Union biofuel strategy; raw material supply was determined as the main element and raw material supply was increased with CAP tools. Tools including premiums (45 euro) and supports given for energy plants per hectare, training- extension works, using idle agricultural lands for this purpose and introducing new technologies to industrialists and producers and etc. has been widely used by the EU. To preclude unstable production numbers among countries, production quotas for biodiesel have been set.

With the intend of having members achieve EU biofuel goals, tax reduction is made at the national level and various tax concessions for producers are provided. Furthermore, R\&D studies are focused on and cost-efficient biofuel production is rapidly going on. The European Biodiesel Board (EBB), which consists of biodiesel producers and directs the biodiesel production around the EU, is an institute that has played an important role in the development of biofuel production and use (Yaşar, 2009; 89).

Germany has a leading role in biodiesel in the EU. Biodiesel is considered within the scope of "Recognition Law for Renewable Energy Resources". As of 2007, 5 \% mixture obligation was imposed in biodiesel and gradual taxation was introduced, but by applying tax exemption for biodiesel's being used as farming fuel, farming for energy was also supported. In France, biodiesel is used with tax-free $5 \%$ blending. (http://www.albiyobir.org.tr/dunyada_b2.htm, Date of Access: 18.08.2018).

\subsection{In Turkey Biodiesel Market and Policies}

Our country has also been affected positively by the rapidly growing biofuel energy in the world economy, and studies on biodiesels have begun to accelerate since the 2000s, especially in biodiesel. In this context, in 2008, the Ministry of Agriculture and Rural Affairs, General Directorate of Agricultural Research Institute has established the "Reseach Center for Energy Crops Cultivation" within the body of Black Sea Agricultural Research Institute, and the research center has been assigned to carry out research and basic projects throughout the country. Supported projects with the establishment of the center vary according to years, while a total of $1.950 .000 \mathrm{TL}$ has been given as support and is still funding (www.tarım.gov.tr). 
As a result of the studies carried out, significant developments related to biodiesel have been recorded due to the increase in the activities in universities and $R$ \& $D$ institutions as well as the increase in energy prices in the world economy. The primary cause of the rapid development of biodiesel in Turkey is that fast-growing diesel technology is able to compete with gasoline-powered vehicles, and that biodiesel compared to diesel fuel is cheaper. Despite the power provided by diesel technology, the fuel cost is less than that of gasoline, and so this cause to prefer diesel in passenger cars.

The first legal regulation of biofuels in Turkey was Petroleum Market Law No. 5015. The law expressed products blended with fuel; products such as methyl tertiary butyl ether (MTBE), ethanol etc. which are and will be subject to equal taxation like fuel, national marker, and additive to be added to the fuel at the refinery exit or at the customs entrance. It also stated that the products obtained from domestic agricultural products and that are blended with fuel cannot be subject to an equivalent tax rate. As a result of the exclusion of excise tax on biodiesel in the law, investments have increased in parallel with the world.

According to the Technical Regulation Communiqué on Diesel Types and the Communiqué on Making Amendments to the Technical Regulation Communiqué on Fuel Oil Types (Fuel Oil Serial No: 22), which entered into force after being published in the Official Gazette dated 27.09.2011 and numbered 28067, the content of fatty acid methyl ester produced from domestic agricultural products of diesel types offered to the market as fuel has to be at least $1 \%$ as of 1.1 .2014 , at least $2 \%$ as of 1.1.2015 and at least $3 \%$ as of 1.1.2016 (Saraçoğlu, 2017; 148).

Nowadays, there are approximately 1.5 million tons of installed biodiesel in our country. That Turkey's annual consumption of diesel and fuel oil is 18-19 million tons clearly shows the size of the total capacity. With this capacity, Turkey ranks second after Germany in the world's biodiesel production capacity considering the installation. In Turkey, with the Decree of the Council of Ministers and the Communiqué of the Ministry of Finance even if entirely domestic agricultural products were used in biodiesel production, a $98 \%$ excise tax on $100 \%$ biodiesel use is practiced. As opposed to petroleum products which are subject to excise tax but free of customs duty, biodiesel is subject to customs duty and, in that way, subject to a high rate of excise duty. Thus, this makes an impact on the development of biofuel sector (http://www.albiyobir.org.tr/).

The amount of biodiesel production in the EU and in Turkey in 2017 and cultivable sites are shown in Table 1. Considering the lands Turkey has and its production capacity, with the right policy, it is feasible to grow adequate oily seeds both for food and fuel. Although Turkey has 23 million 830 thousand hectares of cultivable sites, biodiesel production is only 74 thousand tons. On the contrary, Greece has 2 
million 630 thousand hectares, that is only $10 \%$ of what Turkey has, but can produce 138 thousand tons of biodiesel, which is nearly twice as much as Turkey's. Germany, which is the leader in the EU in biodiesel production, has 11 million 900 thousand hectares of agricultural lands and produces 3 million 17 thousand tons of biodiesel. Another EU member, France has 1 million 703 thousand tons of biodiesel production on its 18 million 510 thousand hectares of cultivable sites. Thereafter comes Spain, Poland and Italy in turn.

Table 1: Biodiesel Production in EU and Turkey (2017)

\begin{tabular}{ccc}
\hline \hline Country & $\begin{array}{c}\text { Amount of Biodiesel } \\
\text { Production (Million Tons) }\end{array}$ & $\begin{array}{c}\text { Agricultural Areas in } \\
\text { Total (Hectares) }\end{array}$ \\
Turkey & 74.000 & 23.830 .000 \\
Germany & 3.017 .000 & 11.900 .000 \\
France & 1.703 .000 & 18.510 .000 \\
Spain & 1.105 .000 & 13.700 .000 \\
Poland & 779.000 & 12.140 .000 \\
Italy & 503.000 & 6.280 .000 \\
Greece & 138.000 & 2.630 .000 \\
\hline \hline
\end{tabular}

Source: https://www.dunya.com/kose-yazisi/enerji-tarimi-sozlesmeli-uretimle-gelisiyor/411895.

Biodiesel blending ratio for the countries are presented in Table2. According to Table 2, it can seen that biodiesel blending ratios in the EU are rather high. In Germany, biodiesel blending around $8 \%$ means carbon emmission at the rate of $4.4 \%$. Biodiesel blending ratio is $7.7 \%$ in France, while biodiesel and bioethanol blending ratios are $5 \%$ in Spain, $7.1 \%$ in Poland, $6.5 \%$ in Italy and $5.75 \%$ in Greece.

Table 2: Biodiesel Blending Ratios in the EU

\begin{tabular}{c||c}
\hline \hline Country & Blending Ratio \\
Austria & $6.3 \%$ Biodiesel \\
Germany & $8 \%$ Biodiesel \\
France & $7.7 \%$ Biodiesel \\
Spain & $5 \%$ Biodiesel+Bioethanol \\
Poland & $7.1 \%$ Biodiesel + Bioethanol \\
Italy & $6.5 \%$ Biodiesel + Bioethanol \\
Greece & $5.75 \%$ Biodiesel + Bioethanol \\
\hline \hline
\end{tabular}

Source:https://www.dunya.com/kose-yazisi/enerji-tarimi-sozlesmeli-uretimle-gelisiyor/411895.

As of 1.1.2018, with the decision of Energy Market Regulatory Committee (EMRC) in Turkey, it has been made compulsory to blend biodiesel in the ratio of $5 \%$. According to this, it is a must to mix each 200 liters of diesel oil with 1 liter of biodiesel, and it is also required to add biodiesel derived from domestic agricultural products or waste oils. By means of this implementation, it is aimed to decrease foreign dependency, to improve resource variety, to recycle waste vegetable oils efficiently, to reduce environmental pollution and to comply with the EU renewable 
energy policies. Biodiesel production of Turkey for the period 2010-2018 is presented in Table 3.

Table 3: Biodiesel Production Amount in Turkey (Million Tons)

\begin{tabular}{cccccccccc}
\hline \hline Years & 2010 & 2011 & 2012 & 2013 & 2014 & 2015 & 2016 & 2017 & $\begin{array}{c}2018 \\
\text { (target) }\end{array}$ \\
\hline $\begin{array}{c}\text { Biodiesel } \\
\text { Production }\end{array}$ & 7.46 & 11.73 & 17.73 & 21.38 & 32.88 & 60.95 & 64.10 & 74.00 & $\begin{array}{c}105 . \\
00\end{array}$ \\
\hline \hline
\end{tabular}

Source: epdk.gov.tr.

As shown in Table 3, biodiesel production in Turkey, which is 7 million 46 thousand liters in 2010, has been steadily increasing. Biodiesel production reached 74 million tons in 2017 and is expected to be 105 million tons in 2018.

\section{Literature Review}

Al-Mulali (2015) investigated the impact of biofuel energy on economic growth, pollution, agriculture price level, and total agriculture production in 16 major biofuel energy consuming countries. The panel model was used in this study for period of 2000-2010. The results showed that biofuel energy increases GDP growth and reduces the level of pollution.

Sen et al (2016), examined the relationships of biofuels production with sustainable development in China by panel data analysis for the 2003 through 2012 periods. They were concluded that the development of biofuel energy production integrated with the consideration of the improvement of income per capita, and the attraction of more capital investment, does make a significant contribution to economic growth.

Zaman et al (2016), empirically measured the environmental impacts of biofuel production in the panel of six largest regions of the World including East Asia \& Pacific, Europe \& Central Asia, Latin America \& Caribbean, Middle East \& North Africa (MENA), South Asia, and Sub Saharan African region, over the period of 1990e2013. Results of study showed that production of biofuels exuberate the Hydrochlorofluorocarbons (HCFCs) in East Asia \& Pacific region, Latin America \& Caribbean region, South Asia, and Sub Saharan African region, while in Europe \& Central Asia, biofuels production significantly lessen the amount of HCFCs in the region.

Alsaleh and Abdul-Rahim (2020), examined the correlation between the bioenergy industry and economic outgrowth. It was found that bioenergy sector factors have a positive and significant impact on economic growth. Also, that there is a longterm 
stable relation among the bioenergy consumption and economic outgrowth. Also, it was derived from the study, there was a significant influence from the bioenergy industry on economic growth in EU-28 region.

Xu et al (2020), examined the nexus among economicg rowth, biofuel consumption, urbanization rate, and $\mathrm{CO} 2$ emissions in seven selected Group of Twenty countries (G20) over 2001-2017. The results of study suggested that the environmental Kuznets curve (EKC) exists between economic growth and $\mathrm{CO} 2$ emissions, and the impact of biofuel consumption and the urbanization rate on $\mathrm{CO} 2$ emissions is negative and positive, respectively.

\section{Methodology, Data and Analysis}

In econometric studies, three types of data are used: time series data, crosssectional data, and mixed data which is combination of time series data and crosssectional data. If the same sectional unit is tracked over time, such mixed data is called panel data. As a result of the measurement of specific sampling units such as individuals, firms, households, cities and countries over time, the panel data structure that expresses data sets for the same audience is reached in different time periods (Baltagi, 2001: 1).

Economic relations are tried to be estimated by using the cross-sectional data of time dimension with panel data analysis (Greene, 1993: 464). Therefore, panel data analysis combines time series and horizontal cross-section series, and allows the creation of a data set with both time and section size.

The results of the study based on the cross-sectional data reveal only the differences between the units. However, in studies using panel data, changes occurring over time in both units and a unit can be revealed.

A simple linear panel data regression model is generally expressed as follows:

$Y_{\text {it }}=\beta_{1 \mathrm{it}}+\beta_{2 \mathrm{it}} \mathrm{X}_{2 \mathrm{it}}+\ldots+\beta_{\text {kit }} X_{\text {kit }}+\varepsilon_{\text {it }}$

$\mathrm{i}=1 \ldots . \mathrm{N} ; \mathrm{t}=1 \ldots . \mathrm{N}$

There are three methods that can be used in the prediction phase with pooled regression as a method of estimation in the adaptation of both time and section data of the model. These methods are:

\section{Classic Model}

2. Fixed Effects Model

3. Random Effects Model

Classic model is a model where both constant and slope coefficients are fixed to units and time. This model is written as follows,

$\mathrm{Y}_{\mathrm{it}}=\beta_{\mathrm{o}}+\sum_{\mathrm{k}=1}^{\mathrm{k}} \beta_{\mathrm{k}} \mathrm{X}_{\mathrm{kit}}+\mathrm{e}_{\mathrm{it}}$ 
and the parameters can be estimated by the Least Squares Method. Below is the general representation of fixed effects model.

$\mathrm{Y}_{\text {it }}=\beta_{1 \mathrm{it}}+\beta_{2 \mathrm{it}} \mathrm{X}_{2 \mathrm{it}}+\ldots+\beta_{\text {kit }} \mathrm{X}_{\mathrm{kit}}+\varepsilon_{\text {it }}$

Random Effects Model is stated as follows;

$\mathrm{Y}_{\text {it }}=\beta_{1 \mathrm{it}}+\beta_{2 \mathrm{it}} \mathrm{X}_{2 \mathrm{it}}+\ldots+\beta_{\mathrm{kit}} \mathrm{X}_{\mathrm{kit}}+\varepsilon_{\mathrm{it}}+\mu_{\mathrm{i}}$

(Greene, 2003; Gujarati, 2004; Narayan and Narayan, 2010; Baltagi, 2001).

\subsection{The Aim of the Study}

This study examined the relationship between the annual series of biodiesel production (thousand tons) and Gross Domestic Product (GDP Million Euro) for 29 countries including Turkey between the years 2008 to 2016 through panel data analysis. Descriptive statistics for the series are given below. These countries are: Belgium, Bulgaria, Czech Republic, Denmark, Germany, Estonia, Ireland, Greece, Spain, France, Croatia, Italy, Cyprus, Latvia, Lithuania, Luxembourg, Hungary, Malta, Netherlands, Austria, Poland, Portugal, Romania, Slovenia, Slovakia, Finland, Sweden, the United Kingdom and Turkey. Data were obtained from Eurostat.

\subsection{Data and Empirical Results}

In this study, it was used annual data for the period 2008-2016 using the Euroean Union and Turkey. Data on biodiesel production are expressed in terms of 1000 tonnes and real GDP series in constant 2010 milyon Euro is used for the economic growth. Descriptive statistics for the relevant series are given in Table 4.

Table 4: Descriptive Statistics for Variables

\begin{tabular}{ccc}
\hline Statistics & GDP & $\begin{array}{c}\text { Biodiesel } \\
\text { (DIESEL) }\end{array}$ \\
\hline \hline Average & 443620.1 & 339.4125 \\
Highest & 2855352. & 2630.900 \\
Lowest & 6373.700 & 0.000000 \\
Standart Deviation & 670799.5 & 566.2255 \\
Skewness & 2.035396 & 2.430750 \\
Kurtosis & 6.145747 & 8.253657 \\
Jarque-Bera & 317.6049 & 614.8212 \\
J\&B p. & $<0,05$ & $<0,05$ \\
\hline \hline $\mathrm{N}$ & 288 & \\
\hline \hline
\end{tabular}

Cross sectional dependence must be analyzed. With the existence of cross sectional dependence, unit root tests taking into account this dependence are required to be 
used. Cross-sectional dependence analyzed by Peseran (2004) Cross-Section Dependence (CD) test. In Peseran CD Test, HO: no cross-sectional dependence

The result of Peseran CD Test was given in Table 5.

Table 5: Peseran CD Test Results

\begin{tabular}{llcc}
\hline \hline & CD Test Statistics & $r$ & $P$ \\
\hline \hline Pesaran CD test & 13.35 & 0.537 & 0.0001 \\
\hline \hline
\end{tabular}

According to $C D$ test results, cross-sectional dependence exists for biodiesel production. Therefore, unit root test for cross-sectional dependent panel data will be used.

If there are cross-sectional dependence between series, then second generation unit root tests must be used for cross sectional dependent series.

IPS (Im, Peseran and Shin) and ADF-Fisher unit root test was applied for economic growth and biodiesel production series and results on unit root tests were given in Table 6.

Table 6: Panel Unit Root Test Results

\begin{tabular}{cccc}
\hline \hline Series & Model & Test & $\mathbf{p}$ \\
\hline \hline \multirow{2}{*}{ Biodiesel } & At the Level & IPS & 0.4727 \\
& At the Level & ADF - Fisher & 0.6319 \\
Biodiesel & first differenced & IPS & $<0.05$ \\
& first differenced & ADF - Fisher & $<0.05$ \\
GDP & At the Level & IPS & 0,8756 \\
& At the Level & ADF - Fisher & 0,9650 \\
GDP & first differenced & IPS & $<0.05$ \\
& first differenced & ADF - Fisher & $<0.05$ \\
\hline \hline
\end{tabular}

When Table 6 is examined, it can be seen that the hypothesis for the biodiesel and GDP series for each of the three tests is not to be rejected with $95 \%$ reliability. Therefore, it can be said that both series are not stationary at the level. However, it is seen that all three series have stabilized after first differentiation process. In the next analysis, it was studied with the series which were stabilized with first difference.

After the unit root tests are applied, it is necessary to perform the cointegration analysis of the panel to determine the long-term relationships between the series (Arouri et al, 2012; 344). According to the results, Westerlund cointegration test 
(the second generation panel cointegration test) should be applied. However, since there were not enough observations, one of the first generation tests, Kao cointegration tests were applied. Kao cointegration test results for the related series were given in Table 7.

Table 7: Kao Cointegration Test Results

\begin{tabular}{llc}
\hline \hline & t-statistics & $\mathbf{p}$ \\
\hline Kao Cointegration Test & 6.0077 & $<0,05$ \\
\hline \hline Error variance & 2.0649 \\
HAC Variance & 1.7188 \\
\hline \hline
\end{tabular}

According to the Kao cointegration test, there is a cointegration between the series. Hausmann Test to examine which panel regression model is valid is given in Table 8.

Table 8: Hausmann Test Results

\begin{tabular}{llll}
\hline \hline Variable & $\begin{array}{l}\text { Chi-Square } \\
\text { Value }\end{array}$ & Statistics & Prob. \\
\hline \hline Biodiesel & 4.97 & 0.0258 \\
\hline \hline
\end{tabular}

HO: valid for random effects model

As a result of the Hausmann test for the hypothesis testing, it is seen that the model of random effects is not valid for GDP-Biodiesel models. It is concluded that unobserved unit effects are fixed effect for the selected country group.

A unit effect model was chosen for the selected country group, however, it was concluded that unobserved unit effects were fixed. Parks-Kmenta estimation method was used for the coefficient estimation and the results are given in Table 9. 
Table 9: Parks- Kmenta Estimation Results

Dependent Variable GDP

Wald Chi-Square Statistics $=\mathbf{5 1 . 7 0}$

Sig.: 0.0001

\begin{tabular}{lcccl}
\hline \hline Independent Variable & Coeff. & $\begin{array}{c}\text { Standart } \\
\text { Error }\end{array}$ & t & Sig. \\
\hline \hline Biodiesel & 805.5129 & 112.0245 & 7.19 & 0.0001 \\
\hline \hline
\end{tabular}

When the fixed effects models are examined, biodiesel series has a positive effect on GDP. Accordingly, the increase in biodiesel production affects the GDP in an upward direction.

\section{Conclusion and policy implications}

Nowadays, due to the reasons such as the decrease in oil reserves, the rapid increase in prices of petroleum products, the reduction of pollutant exhaust gases as a result of the combustion of them and the standards developed related to air pollution control, and reducing the dependence on the outside, etc, the studies for the development of alternative fuels have gained speed. One of the alternative fuels investigated for diesel engines is biodiesel. Biodiesel is obtained from waste frying oil from agricultural products such as canola, rapeseed, soy, safflower, flax, sunflower, and corn, or from animal fats. In addition, low-cost raw materials such as yellow grease and brown grease, which include waste frying oils, animal fats and various waste oils, can be used. As biodiesel properties vary depending on the oil source used and the type of alcohol used in production, the ignition, combustion and emission values for each biodiesel are different from each other.

Biodiesel is produced from high quality vegetable oils. Prices of vegetable oils used as food being high and the cost of biodiesel production depending largely on the price of raw materials increase the price of biodiesel unit and, despite its many advantages, it prevents the widespread use of biodiesel. In order to reduce the high price of biodiesel and enable it to compete with diesel fuel, various biodiesel incentive programs have been introduced in the countries. Incentives have been applied in the biofuel industry, include various subsidies to agricultural products to be used in biodiesel production, grants and loans to projects for development of second generation biofuels, opening of marginal lands to production, application of base price to $C 4$ energy crop producers, low interest loan supports for $R \& D$ activities, various tax deductions and subsidies,

As a result of the econometric analysis carried out, a cointegration between the series was determined by Kao cointegration method. After the cointegration structure was revealed, by accepting GDP as dependent variable, it was found that the effect was positive in all models according to the panel model estimation results. Then as a result of Hausmann test, it was seen that the model of random 
effects is valid for GDP-Biodiesel models. Examining the fixed effects models, it was determined that biodiesel series has a positive effect on GDP. As biodiesel fuel is a completely domestic source of energy in terms of raw material, it will reduce foreign dependency in energy, and thus decrease in energy import costs will lead to an increase in GDP.

Biodiesel sector will make great contributions to the provision of sustainable energy in the EU and Turkey which meet a significant part of energy demand through imports and to the goal of reaching low-carbon economy in the future. To achieve this, the incentives given by the state for biodiesel production, processing and consumption stages must be maintained because of favorable climatic conditions, the amount of land, soil and agricultural potential in terms of the EU and Turkey.

\section{Acknowledgments}

This work was supported by the Commission of Scientific Research Projects of Eskişehir Osmangazi University (ESOGU) with the project number 2017-1843. 


\section{References}

Al-Mulali U. (2015). The Impact of Biofuel Energy Consumption on GDP Growth, Co2 Emission, Agricultural Crop Prices, and Agricultural Production, International Journal of Green Energy, 12(11), 1100-1106

Alsaleh M. and A. S. Abdul-Rahim A.S. (2020). Bioenergy Consumption and Economic Growth in the EU-28 Region: Evidence from a Panel Cointegration Model, GeoJournal, 1-16.

Aransiola, E.F., Ojumu T.V., Oyekola, O.O., Madzimbamuto and Iknu-Omoregbei D.I.O. (2014). A Rewiev of Current Technology for Biodiesel Production: State of the art, Bıomass and Bıoenergy, 61, 276-297.

Arouri, M. El H., Youssef, A.B., M'hennş, H. and Rault C. (2012). Energy consumption, economic growth and $\mathrm{CO} 2$ emission in Middle East and North African countries, Energy Policy, 45, 342-349.

Aytüre, S. (2013). Avrupa Birliğinin Enerji Politikasında Son Gelişmeler ve Türkiye'ye Yansımaları, Nevşehir Hacı Bektaş Veli Üniversitesi, Sosyal Bilimler Enstitüsü Dergisi, 3, 35-51.

Baltagi, B (2001). Econometric Analysis of Panel Data, 2nd Ed., UK: John Wiley \& Sons Ltd.

Bayraç, H. N. ve Çelikay, F. ve Çildir, M. (2018). Küreselleşme Sürecinde Sürdürülebilir Enerji Politikaları, Ekin Yayınları, Bursa.

Çelebi, K. A. ve Uğur A. (2015). Biyoyakıtlara Yönelik Mali Teşvikler: Türkiye Açısından Bir Değerlendirme, Hacettepe Üniversitesi IiBF Dergisi, 33 (2), 25-45.

Dağdelen D. (2015). Küresel Biyoyakıt Politikalarının $A B$ ve Türkiye Açısından incelenmesi, T.C. Gıda Tarım ve Hayvancılık Bakanlığı, Avrupa Birliği ve Dış İlişkiler Genel Müdürlüğü, AB Uzmanlık Tezi, Ankara.

Eurostat (2016). 2020 Climate and Energy Package, (https://ec.europa.eu/clima/policies/energy-stragety/2030-energy-strategy, Date of Access: 18.08.2018).

Greene, W. H. (2003). Econometric analysis. Pearson Education India.

Gujarati, D. (2004). Basic Econometrics. United States Military Academy, West Point.

Horuz, A. ve Korkmaz A, ve Akınoğlu, G. (2015). Biyoyakıt Bitkileri ve Teknolojisi, Toprak Bilimi ve Bitki Besleme Dergisi, 3 (2), 69-81.

Karaosmanoğlu, F. (2002). Ekojenerasyon Dünyası, Ekojenerasyon Dergisi, ICCI Özel Sayısı, 10, 50-56. 
Narayan, P. K. and Narayan, SD. (2010). Carbon Dioxside Emission and Economic Growth: Panel Data Evidence from Developing Countries, Energy Policy, 38, 661666.

Özertan G. (2008). Biyoyakıtların Türkiye'nin Enerji, Tarım, Çevre ve Kırsal Kalkınma Politikaları İçin Önemi, iktisat-Işletme ve Finans Dergisi, 23 (262), 17-34.

Pesaran, M. H. (2004). General Diagnostic Tests for Cross Section Dependence in Panels. University of Cambridge, Faculty of Economics, Cambridge Working Papers in Economics No. 0435.

Saraçoğlu, S. (2017). Yenilenebilir Enerji Kaynağı Olarak Biyokütle Üretiminin Dünyada ve Türkiye'de Durumu, Fiscaoeconomia, 1 (3), 126-155.

Sen Qiao, Xin-long Xu, Cheng Kun Liu and Hsing Hung Chen (2016). A Panel Study on the Relationship Between Biofuels Production and Sustainable Development, International Journal of Green Energy, 13 (1), 94-101.

Wetterlund, E.ve Leduc. S.ve Dotzauer, E. and Kindermann, G. (2012). Optimal Localisation of Biofuel Production on a European Scale, Energy, 41, 789-800.

Xu B., Zhong R. and Qiao H. (2020). The Impact of Biofuel Consumption on CO2 Emissions: A Panel Data Analysis for Seven Selected G20 Countries, Energy and Environment, 31(8), 1498-1514.

Yaşar, B. (2009). Alternatif Enerji Kaynağı Olarak Biyodizel Üretim ve Kullanım Olanaklarının Türkiye Tarımı ve Ab Uyum Süreci Açısından Değerlendirilmesi, Çukurova Üniversitesi, FBE, Tarım Ekonomisi ABD, Doktora Tezi, Adana.

Yorkan, A. (2009). AB’nin Enerji Politikası ve Türkiye'ye Etkileri, Bilge Strateji, 1 (1), 24-39.

Zaman K., Awan U., Islam T., Paidi R., Hassan and A., Alias bin Abdullah, (2016). Econometric Applications for Measuring The Environmental Impacts of Biofuel Production in The Panel Of Worlds' Largest Region, International Journal of Hydrogen Energy, 41(7), 4305-4325.

http://ec.europa.eu/eurostat/tgm/table.do?tab=table\&init=1\&language=en\&pco de=tsdcc310\&plugin=1/ Date of Access: 14.08.2018.

https://www.intechopen.com/books/biofuel-s-engineering-processtechnology/novel-methods-in-biodiesel-production/ Date of Access: 04.08.2018.

http://www.albiyobir.org.tr/dunyada_b2.htm/date of access: 18.08.2018.

https://www.dunya.com/kose-yazisi/enerji-tarimi-sozlesmeli-uretimlegelisiyor/411895/ Date of Access: 18.08.2018.

www.tarım.gov.tr/ Date of Access: 18.08.2018. 